\title{
PROGNOSIS OF DURABILITY OF CONCRETE BY EVALUATING FREEZING AND THAWING CYCLES
}

Raimondas ŠADZEVIČIUS, Department of Water Engineering, Faculty of Engineering, Vytautas MagnusUniversity, K. Donelaičio g. 58, LT-44248 Kaunas, Lithuania, raimundas.sadzevicius@vdu.lt (corresponding author) Dainius RAMUKEVIČIUS, Department of Water Engineering, Faculty of Engineering, Vytautas MagnusUniversity, K. Donelaičio g. 58, LT-44248 Kaunas, Lithuania, dainius.ramukevicius@vdu.lt

Tatjana SANKAUSKIENĖ, Department of Water Engineering, Faculty of Engineering, Vytautas MagnusUniversity, K. Donelaičio g. 58, LT-44248 Kaunas, Lithuania, tatjana.sankauskiene@ vdu.lt

Justyna DZIECCIOL, Department of Hydrotechnics, Technology and Management, Institute of Civil Engineering, Warsaw University of Life Sciences, Nowoursynowska 159,02776 Warsaw, Poland, justyna_dzieciol1@sggw.edu.pl

Katarzyna GABRYŚ, Water Centre WULS, Warsaw University of Life Sciences, Ciszewskiego 6- 49, 02786, Warszawa, Poland, katarzyna_gabrys@sggw.edu.pl

Hydraulic structures are exploited in hard environmental conditions (impact of freeze-thaw cycling, ultraviolet, humidity and drying, acidity or salinity of water, abrasion etc.), so due to the impact of environmental factors some deteriorations will occur. The repeated cycles of freezing and thawing have significant effects on durability of concrete. They reducing durability, because of cracking and scaling of concrete. Using the research results of investigated hydraulic structures concrete average compression strength $f_{c k}$, water absorption by weight $W_{m}$, by formulae $(1,2)$ were calculated numbers of laboratory freeze-thaw cycles $n_{50}$, freeze-thaw resistance of concrete rate $F_{5} \%$ and from them - durability index - probable deterioration start time $T_{5} \%$ of investigated main hydraulic structures .( concrete strength $f_{\text {ck }}$ loss in $5 \%$ and 5 freeze-thaw cycles per year).

Relationships between shaft spillway or retaining wall freeze-thaw resistance of concrete rate $F_{5} \%$, durability index $T_{5} \%$, and average compression strength of concrete $f_{c k}$ were evaluated. These equations may be used for the durability prognosis of existing shaft spillways or retaining walls exploited in hydraulic structures.

Keywords: freeze-thaw cycling, durability of concrete, hydraulic structures.

\section{INTRODUCTION}

The parts of main hydraulic structures - surplus water fall spillway (drop inlet, siphon, bucket, etc.) or spillway (rapids, piers, retaining walls, etc.) and downstream structures in stilling basin (retaining walls, downstream apron, slabs for protection of downstream channel) are made of reinforced concrete elements, which determines the reliability of the whole hydroscheme.

Reinforced concrete is a long-lasting and sustainable material, but it wears out when exposed to the environment. One of the most significant indicators of the durability of reinforced concrete structures is the freeze-thaw (hereinafter - F$\mathrm{T})$ resistance of concrete. There are many theories explaining how freezing and thawing causes damage to concrete (Hamoush et al., 2011; Gjørv, 2013). Such theories include: critical saturation, hydraulic pressure, ice accretion and osmotic pressure (Beaudoin et al., 2009; Mustafa et al., 2009).

Hydraulic pressure theory states that the buildup of hydraulic pressure from the resistance to flow of unfrozen water through capillaries causes damage to the concrete (Hamoush et al., 2011). The main cause of concrete cracking, crushing and shrinkage is the conversion of freezing water into ice in concrete pores. Ice occupies $9 \%$ more volume than water, so ice crystals creates hydraulic pressure inside the concrete pores and capillaries, expand the entire concrete structure and when it has no more room to expand - cracks can appear.

The magnitude of the hydraulic pressure force depends on the level of water filling in the pores and the cooling rate. If the water saturation is less than $75 \%$ of the pores, the freezing water pressure is not dangerous. In addition, it is believed that osmotic pressure forces act on freezing concrete due to the presence of dissolved salts in the water. As water turns to ice, the concentration of the solution increases and osmotic phenomena occur through the pore walls. Osmotic pressure forces can increase ice crystallization forces.

The degradation process of concrete element starts when the freezing water expansive forces exceed the tensile strength in the concrete. The mechanically stronger concrete has less water in its open pores and is more resistant to frost impact. 
The concrete water absorption by weight (hereinafter - absorption) and freeze-thaw resistance depend on the porosity of the material structure, the size of the pores and capillaries and the type of pores. Pores can be open or closed. Open pores increase the water absorption of concrete and reduce frost resistance. Open pores and capillaries are formed during the hardening of concrete by evaporation of unused (free) water for hydration. Closed pores are formed during the hardening of concrete by the incorporation of air from the environment into the concrete mass and by the compression of the hardening cement stone. The inclusion of air promotes, as well as some special additives increase the concrete's resistance to frost to a certain level.

The European Standard, EN 206:2013, provides recommended specifications for designing concrete in certain exposure conditions. There are 4 specific exposure classes (XF1...XF4) for dealing with freeze-thaw attack with or without de-icing agents.

The freeze-thaw resistance of concrete is determined by alternately (cyclically) freezing water-saturated concrete samples in air and then thawing them in water or saline. There are several standardized methods for determining (F-T) cycles, but testing them requires a lot of time and labor. In the European standards (CEN/TR 15177:2006) three different methods (Slab-Test, CIF-method and Cube test) are mentioned for the estimation of the freeze-thaw resistance of concrete with regard to internal structural damage. European, Lithuanian and Russian standards (Setzer et. al., 1996; CEN/TS 12390-9; LST 1428.19:2016; GOST 10060-87, 1987) are used for the evaluation of frost related damage to concrete structures too. Therefore, methods are being sought that allow the determination of the freeze-thaw resistance of concrete indirectly - based on easier-to-determine indicators.

Aim of research. To evaluate the freeze-thaw resistance of concrete used in hydraulic structures and to predict the durability of investigated main structures in upper (shaft culverts) and lower (retaining walls in stilling basein) pool.

Object of research. The investigated main hydraulic structures in upper and lower pool in 36 hydroschemes are in the territory of Lithuania. The main attention is focused on Alytus (1 hydroscheme), Anykščiai (4 hydroschemes), Joniškis (3 hydroschemes), Kaunas (6 hydroschemes), Kèdainiai (3 hydroscheme), Marijampole (6 hydroschemes), Pakruojis (2 hydroschemes), Radviliškis (3 hydroschemes), Raseiniai (2 hydroschemes), Šiauliai (4 hydroschemes) and Ukmergè (2 hydroschemes).

\section{METHODS OF FIELD INVESTIGATIONS AND LABORATORY TESTS}

The concrete can deteriorate under freezing and thawing cycles. Using the field investigations and laboratory tests ( standard methods) the main physical - mechanic properties of main hydraulic structures - their concrete compression strength and water absorbability were determined and statistically evaluated. These properties are necessary for the evaluation of changes in concrete properties under freeze-thaw cycles, for the calculations of the constant of deterioration and the parameters of the durability of structures.

The compression strength of functioning concrete hydraulic structures was evaluated by the non-destructive method (EN 12504-2: 2021) and testing the samples of irregular shape (Vaišvila, Mikutskis, 2005). The non-destructive testing of compressive strength was performed in accordance with the European Standard EN 12504-2:2021 "Testing concrete in structures. Part 2. Non-destructive testing. Determination of rebound number" using the calibrated rebound device - the rebound hammer of concrete, Schmidt's hammer, which was calibrated using the standard anvil before and after every examination.

The concrete compression strength of samples is evaluated by an ordinary compression test. For this purpose hydraulic or lever compression machines are used in accordance with the standard requirements. The concrete compression strength of the samples of irregular shape was calculated into concrete compressive strength of standard cubes of $100 \times 100 \times 100 \mathrm{~mm}$. Such an evaluation was accomplished by means of the proposed formulae and corresponding coefficients.

From the statistically evaluated research results of hydraulic structures concrete compression strength, water absorbability and the rates of freeze-thaw resistance of concrete were calculated. We used a new, nonstandard freezethaw resistance mark determination method, developed by the researchers of Vytautas Magnus University (former Lithuanian University of Agriculture), where this property is approximately evaluated by concrete compression strength and water absorbability.

Knowing the compression strength $f_{c k}$ of the concrete (EN 12390-3: 2009; EN 12504-1: 2009; EN 12504-2: 2021; EN 13791:2007) water absorbability by mass $W_{m}$ (EN 12390- 8: 2009) and allowed or forecasted loss of the concrete strength $\Delta f_{c}$, it is possible to estimate laboratory (F-T) cycles number $n_{50}(\mathrm{GOST} 10060-87,1987)$ :

$$
n_{50 .}=c \cdot \Delta f_{c}^{-d}
$$

where $\quad n_{50-}$ numbers of laboratory (F-T) cycles freezing samples until $-55 \pm 2^{\circ} \mathrm{C}$ by (GOST 10060-87, 1987), $\Delta f_{c k}$ - concrete strength loss in \% due the influence of (F-T) cycles, calculated by (LST 1428.19:2016), $c, d$-coefficients found in the tables made by the researchers of Vytautas Magnus University.

The freeze-thaw resistance of concrete mark $F$ shows the number of (F-T) cycles $n_{\mathrm{F}}$ when samples are frozen in $18 \pm 2^{\circ} \mathrm{C}$, so the number of standard (F-T) cycles is calculated according to the formula developed by the researchers of Vytautas Magnus University: 


$$
n_{F .}=34.848 \cdot n_{50}^{0.6157}
$$

Function determination coefficient $R^{2}=0.9947$.

Evaluating the impact of (F-T) cycles to the change of investigated structures concrete physical- mechanic properties the freeze-thaw resistance of concrete parameters $F_{5} \%$ were used.

According to LST 1428.19:2016, deterioration beginning was fixed by the number of cycles, when from freezing the sample surface $5 \%$ of sample mass (freeze-thaw resistance index $F_{5 \%}$ ) deteriorate). From the first observed deterioration symptoms till absolute deterioration of the surface some time passes.

Natural (F-T) cycles, by means of corrective coefficients (chosen according to the graph elaborated by the researchers of Vytautas Magnus University), were recounted into the laboratory (F-T) cycles and further recalculated to the parameters of structures durability - probable deterioration time $T_{5} \%$ (the probable deterioration start time).

Dependences established between concrete physical - mechanical properties obtained by the field investigations and laboratory tests and calculated parameters of structures durability $T_{5} \%$,were examined by methods of correlation analysis. Formulae of dependences were established, correlation coefficients calculated and their reliability evaluated.

\section{RESEARCH RESULTS}

During field investigations, the main attention was focused on Alytus, Anykščiai, Joniškis, Kaunas, Kèdainiai, Marijampolè, Pakruojis, Radviliškis, Raseiniai, Šiauliai and Ukmerge districts. The main reinforced concrete hydraulic structures in upper and lower pool were selected for detailed analysis. Average compression strength $f_{\text {ck }} \mathrm{MPa}$, concrete water absorption by weight $W_{m} \%$, numbers of laboratory (F-T) cycles $n_{50}$, freeze-thaw resistance of concrete rate $F_{5} \%$; probable deterioration start time $T_{5} \%$ of investigated main hydraulic structures are presented in Table 1 .

According to the results presented in Table. 1 the lowest values of concrete average compression strength $f_{\text {ck }}$ was founded in Panevėžiukas shaft spillway $\left(f_{\mathrm{ck}}=6.0 \mathrm{MPa}\right)$ and in Antanavas HPS and Savičiūnai retaining walls $\left(f_{\mathrm{ck}}=5.8\right.$ $\mathrm{MPa})$. The highest values of concrete average compression strength was founded in Angiriai shaft spillway $\left(f_{\mathrm{ck}}=27.6\right.$ $\mathrm{MPa})$ and in Akademija retaining walls in stilling basin $\left(f_{\mathrm{ck}}=27.9 \mathrm{MPa}\right)$.

The highest values of concrete water absorption by weight $W_{m}$ was founded in Panevėžiukas shaft spillway $\left(W_{m}\right.$ $=13.8 \%)$ and in Antanavas HPS and Savičiūnai retaining walls $\left(W_{m}=14.1 \%\right)$.

Table 1. Evaluation of durability index $T_{5} \%$ of investigated main hydraulic structures

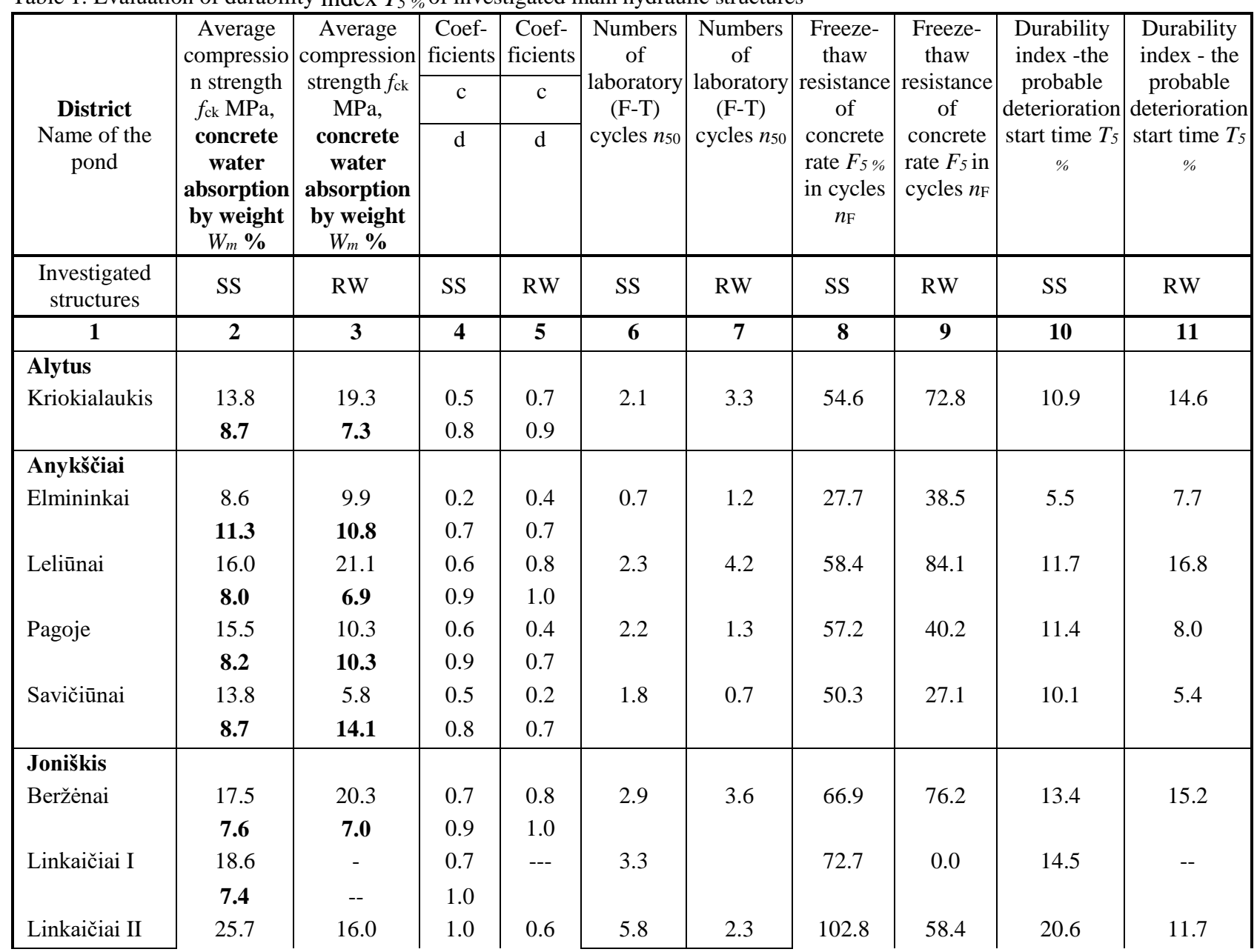




\begin{tabular}{|c|c|c|c|c|c|c|c|c|c|c|}
\hline & 6.2 & 8.0 & 1.1 & 0.9 & & & & & & \\
\hline \multicolumn{11}{|l|}{ Kaunas } \\
\hline \multirow[t]{2}{*}{ Altoniškiai } & 22.4 & 15.8 & 0.9 & 0.6 & 4.4 & 2.3 & 86.9 & 57.5 & 17.4 & 11.5 \\
\hline & 6.7 & 8.1 & 1.0 & 0.9 & & & & & & \\
\hline \multirow[t]{2}{*}{ Babtai I } & 21.1 & 13.8 & 0.8 & 0.5 & 4.2 & 2.1 & 84.1 & 54.6 & 16.8 & 10.9 \\
\hline & 6.9 & 8.7 & 1.0 & 0.8 & & & & & & \\
\hline \multirow[t]{2}{*}{ Babtai II } & 9.4 & 11.7 & 0.4 & 0.4 & 1.2 & 1.5 & 39.5 & 45.2 & 7.9 & 9.0 \\
\hline & 10.7 & 9.6 & 0.7 & 0.8 & & & & & & \\
\hline \multirow[t]{2}{*}{ Gailiušiai } & 10.3 & 15.6 & 0.4 & 0.6 & 1.3 & 2.2 & 40.2 & 57.2 & 8.0 & 11.4 \\
\hline & 10.2 & 8.2 & 0.7 & 0.9 & & & & & & \\
\hline \multirow[t]{2}{*}{ Gaižènai } & 21.8 & 19.7 & 0.9 & 0.7 & 4.2 & 3.5 & 84.7 & 75.6 & 16.9 & 15.1 \\
\hline & 6.8 & 7.2 & 1.0 & 1.0 & & & & & & \\
\hline \multirow[t]{2}{*}{ Panevėžiukas } & 6.0 & 8.4 & 0.2 & 0.3 & 0.6 & 1.0 & 25.4 & 34.6 & 5.1 & 6.9 \\
\hline & 13.8 & 11.5 & 0.6 & 0.7 & & & & & & \\
\hline \multicolumn{11}{|l|}{ Kèdainiai } \\
\hline \multirow[t]{2}{*}{ Akademija } & 16.2 & 27.9 & 0.6 & 1.1 & 2.3 & 6.1 & 58.6 & 105.9 & 11.7 & 21.2 \\
\hline & 8.0 & 5.9 & 0.9 & 1.1 & & & & & & \\
\hline \multirow[t]{2}{*}{ Angiriai } & 27.6 & 18.7 & 1.0 & 0.6 & 6.0 & 2.3 & 105.5 & 58.4 & 21.1 & 11.7 \\
\hline & 6.0 & 7.4 & 1.1 & 0.9 & & & & & & \\
\hline \multirow[t]{2}{*}{ Kruostas HPP } & 12.8 & 18.3 & 0.5 & 0.6 & 1.6 & 2.3 & 46.7 & 58.2 & 9.3 & 11.6 \\
\hline & 9.1 & 7.5 & 0.8 & 0.9 & & & & & & \\
\hline \multicolumn{11}{|l|}{ Marijampolė } \\
\hline \multirow{2}{*}{$\begin{array}{l}\text { Antanavas } \\
\text { HPS }\end{array}$} & 11.2 & 5.8 & 0.4 & 0.2 & 1.4 & 0.7 & 43.4 & 27.1 & 8.7 & 5.4 \\
\hline & 9.8 & 14.1 & 0.8 & 0.7 & & & & & & \\
\hline \multirow[t]{2}{*}{ Ąžuolų Būda } & -- & 9.6 & & 0.4 & & 1.2 & & 39.8 & -- & 8.0 \\
\hline & -- & 10.7 & & 0.7 & & & & & & \\
\hline \multirow[t]{2}{*}{ Jūrè } & 12.3 & 9.8 & 0.5 & 0.4 & 1.6 & 1.2 & 47.0 & 39.0 & 9.4 & 7.8 \\
\hline & 9.3 & 10.5 & 0.8 & 0.7 & & & & & & \\
\hline \multirow[t]{2}{*}{ Kazlai } & 10.4 & 11.7 & 0.4 & 0.4 & 1.3 & 1.5 & 40.5 & 45.2 & 8.1 & 9.0 \\
\hline & 10.2 & 9.6 & 0.7 & 0.8 & & & & & & \\
\hline \multirow[t]{2}{*}{ Marijampolè } & 13.8 & -- & 0.5 & & 1.8 & & 50.3 & 0.0 & 10.1 & -- \\
\hline & 8.7 & -- & 0.8 & & & & & & & \\
\hline \multirow[t]{2}{*}{ Netičkampis } & 21.6 & 16.3 & 0.9 & 0.6 & 4.9 & 2.4 & 92.9 & 59.2 & 18.6 & 11.8 \\
\hline & 6.8 & 8.0 & 1.0 & 0.9 & & & & & & \\
\hline Pakruojis & & & & & & & & & & \\
\hline Baltausiai & 17.0 & 15.5 & 0.7 & 0.6 & 3.0 & 2.2 & 68.8 & 57.2 & 13.8 & 11.4 \\
\hline & 7.8 & 8.2 & 0.9 & 0.9 & & & & & & \\
\hline Laičiai I & 7.8 & 16.0 & 0.3 & 0.6 & 0.9 & 2.3 & 32.0 & 58.4 & 6.4 & 11.7 \\
\hline & 11.9 & 8.0 & 0.7 & 0.9 & & & & & & \\
\hline Radviliškis & & & & & & & & & & \\
\hline Arimaičiai & 16.1 & 16.2 & 0.6 & 0.6 & 2.3 & 2.3 & 58.8 & 58.9 & 11.8 & 11.8 \\
\hline & 8.0 & 8.0 & 0.9 & 0.9 & & & & & & \\
\hline Baisogala II & 16.4 & 19.1 & 0.6 & 0.7 & 2.4 & 3.2 & 59.2 & 71.7 & 11.8 & 14.3 \\
\hline & 7.9 & 7.3 & 0.9 & 0.9 & & & & & & \\
\hline Gulbinai & 18.0 & 7.6 & 0.7 & 0.3 & 3.0 & 0.9 & 68.2 & 31.6 & 13.6 & 6.3 \\
\hline & 7.5 & 12.1 & 0.9 & 0.7 & & & & & & \\
\hline Raseiniai & & & & & & & & & & \\
\hline Anulynas & 17.8 & 16.5 & 0.7 & 0.6 & 2.9 & 2.4 & 67.4 & 59.5 & 13.5 & 11.9 \\
\hline & 7.6 & 7.9 & 0.9 & 0.9 & & & & & & \\
\hline Plikiai & 19.6 & 17.4 & 0.7 & 0.7 & 3.3 & 2.9 & 73.3 & 66.9 & 14.7 & 13.4 \\
\hline & 7.2 & 7.7 & 0.9 & 0.9 & & & & & & \\
\hline $\begin{array}{l}\text { Šiauliai } \\
\text { Dargaičiai }\end{array}$ & 23.6 & 12.5 & 0.9 & 0.5 & 4.6 & 1.6 & 88.9 & 46.6 & 17.8 & 9.3 \\
\hline
\end{tabular}




\begin{tabular}{|c|c|c|c|c|c|c|c|c|c|c|}
\hline \multirow{3}{*}{ Gudeliai } & 6.5 & 9.2 & 1.0 & 0.8 & \multirow{3}{*}{2.2} & \multirow{3}{*}{2.1} & \multirow{3}{*}{57.2} & \multirow{3}{*}{54.4} & \multirow{3}{*}{11.4} & \multirow{3}{*}{10.9} \\
\hline & 15.5 & 13.7 & 0.6 & 0.5 & & & & & & \\
\hline & 8.2 & 8.8 & 0.9 & 0.8 & & & & & & \\
\hline \multirow[t]{2}{*}{ Kairiai } & 10.4 & 14.2 & 0.4 & 0.5 & \multirow[t]{2}{*}{1.3} & \multirow[t]{2}{*}{2.1} & \multirow[t]{2}{*}{40.5} & \multirow[t]{2}{*}{55.2} & \multirow[t]{2}{*}{8.1} & \multirow[t]{2}{*}{11.0} \\
\hline & 10.2 & 8.6 & 0.7 & 0.8 & & & & & & \\
\hline \multirow[t]{2}{*}{ Šakyna } & 16.4 & 19.0 & 0.6 & 0.7 & \multirow[t]{2}{*}{2.4} & \multirow[t]{2}{*}{3.2} & \multirow[t]{2}{*}{59.2} & \multirow[t]{2}{*}{71.7} & \multirow[t]{2}{*}{11.8} & \multirow[t]{2}{*}{14.3} \\
\hline & 7.9 & 7.3 & 0.9 & 0.9 & & & & & & \\
\hline \multicolumn{11}{|l|}{ Ukmergè } \\
\hline \multirow[t]{2}{*}{ Kadrènai } & 16.9 & 18.3 & 0.7 & 0.7 & \multirow[t]{2}{*}{3.0} & \multirow[t]{2}{*}{3.1} & \multirow[t]{2}{*}{68.8} & \multirow[t]{2}{*}{69.6} & \multirow[t]{2}{*}{13.8} & \multirow[t]{2}{*}{13.9} \\
\hline & 7.8 & 7.5 & 0.9 & 0.9 & & & & & & \\
\hline \multirow[t]{2}{*}{ Virkščiai } & 13.0 & 18.8 & 0.5 & 0.7 & \multirow[t]{2}{*}{1.8} & \multirow[t]{2}{*}{3.1} & \multirow[t]{2}{*}{49.3} & \multirow[t]{2}{*}{70.2} & \multirow[t]{2}{*}{9.9} & \multirow[t]{2}{*}{14.0} \\
\hline & 9.0 & 7.4 & 0.8 & 0.9 & & & & & & \\
\hline
\end{tabular}

SS - Shaft Spillway;

RW - Retaining walls in stilling basin;

HPS - hydropower station.

According to the results presented in Table. 1 the durability index - probable deterioration start time $T_{5} \%$ with concrete strength $f_{\text {ck }}$ loss in $5 \%$ and 5 (F-T) cycles per year for shaft spillway reinforced concrete stuctures varies from 5.1 (Panevėžiukas) to 21.1 (Angiriai) years, and for retaining walls in stilling basin varies from 5.4 (Antanavas HPS and Savičiūnai) to 21.2 (Akademija) years.

The dependencies of shaft spillway reinforced concrete stuctures durability index - probable deterioration start time $T_{5} \%$, freeze-thaw resistance of concrete rate $F_{5} \%$ and average compression strength $f_{\text {ck }}$ are drawn in Figure 1 .
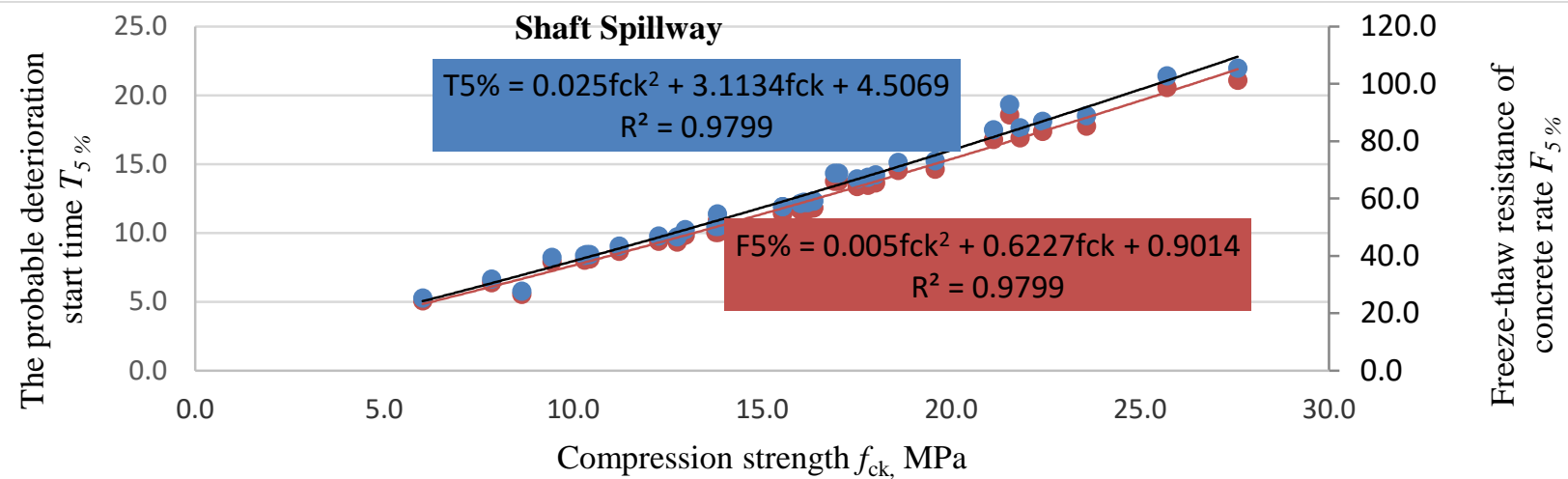

Figure 1. Relationship between shaft spillway durability index $T_{5} \%$, freeze-thaw resistance of concrete rate $F_{5} \%$ and average compression strength of concrete $f_{c k}$

The dependencies of retaining walls reinforced concrete stuctures freeze-thaw resistance of concrete rate $F_{5} \%$, durability index - probable deterioration start time $T_{5} \%$ and average compression strength $f_{\text {ck }}$ are drawn in Figure 2.

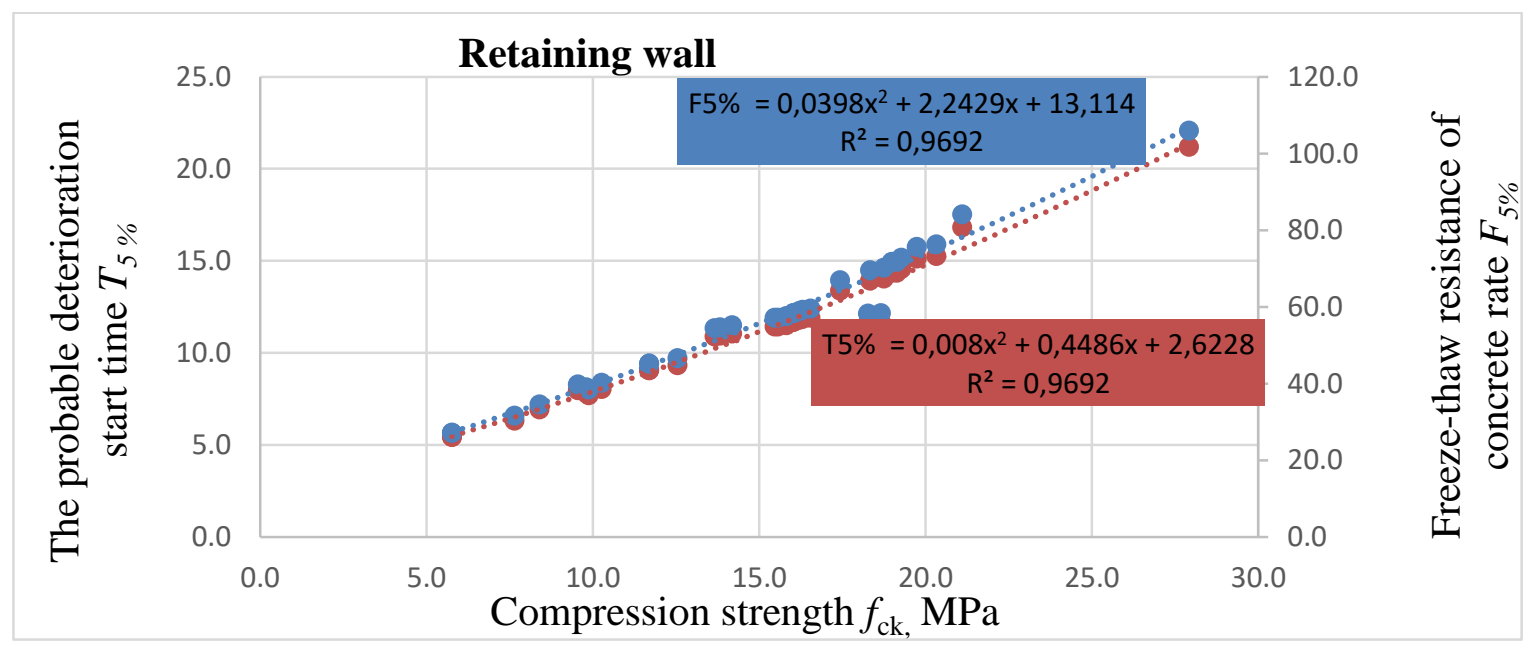

Figur 2. Relationship between retaining wall durability index $T_{5} \%$, freeze-thaw resistance of concrete rate $F_{5} \%$ and average compression strength of concrete $f_{c k}$ 
Concrete average compression strength's $f_{c k}$ and durability index $T_{5 \%}$ and freeze-thaw resistance of concrete rate $F_{5 \%}$ reliability of functional dependences was checked by double correlation. It was found, that dependences are strong $\left(r_{x y}\right.$ 0,96...0,98). Calculated correlation coefficients are reliable, their importance level $p<0,05$. The established determination coefficients $R^{2}=0.9799$ and $R^{2}=0.9692$, therefore can be stated that examined strength parameters influence investigated index of durability by $97.99 \%$ and $96.92 \%$, other part belongs to the influence of less important parameters.

\section{CONCLUSIONS}

1. According to the results of investigated main hydraulic structures in upper and lower pool in 36 hydroschemes: the lowest values of concrete average compression strength $f_{\text {ck }}$ was founded in Panevėžiukas shaft spillway $\left(f_{\text {ck }}=6.0\right.$ $\mathrm{MPa})$ and in Antanavas HPS and Savičiūnai retaining walls $\left(f_{\mathrm{ck}}=5.8 \mathrm{MPa}\right)$. The highest values of concrete average compression strength was founded in Angiriai shaft spillway $\left(f_{\mathrm{ck}}=27.6 \mathrm{MPa}\right)$ and in Akademija retaining walls in stilling basin $\left(f_{\mathrm{ck}}=27.9 \mathrm{MPa}\right)$;

the highest values of concrete water absorption by weight $W_{m}$ was founded in Panevėžiukas shaft spillway $\left(W_{m}\right.$ $=13.8 \%)$ and in Antanavas HPS and Savičiūnai retaining walls $\left(W_{m}=14.1 \%\right)$.

2. Using results of calculated freeze-thaw resistance of concrete rate $F_{5} \%$ were calculated the durability indexes probable deterioration start time $T_{5} \%$ (with concrete strength $f_{\mathrm{ck}}$ loss in $5 \%$ and $5(\mathrm{~F}-\mathrm{T})$ cycles per year) for investigated structures:

for shaft spillway reinforced concrete stuctures $T_{5} \%$ varies from 5.1 (Panevėžiukas) to 21.1 (Angiriai) years;

for retaining walls in stilling basin $T_{5} \%$ varies from 5.4 (Antanavas HPS and Savičiūnai) to 21.2 (Akademija) years.

3. Dependences established between concrete physical - mechanical properties obtained by the field investigations and laboratory tests and calculated parameters of structures durability $T_{5} \%$ may be used for the durability prognosis of existing shaft spillways or retaining walls exploited in hydraulic structures.

\section{REFERENCES}

1. Beaudoin J.J., L. Raki R. Alizadeh, L.D. Mitchell, 2009. Dimensional change and elastic behavior of layered silicates and portland cement paste. Cement Concrete Compos, Vol. 32, pp. 25-33. https://doi.org/10.1016/j.cemconcomp.2009.09.004

2. Setzer M. J., Fagerlund G., Janssen D. J. 1996. CDF Test - Test method for the freeze-thaw resistance of concrete - tests with sodium chloride solution (CDF), RILEM Recommendation TC 117-FDC: 'Freeze-thaw and de-icing resistance of concrete', Materials and Structures, Vol. 29, pp. 523-528. https://doi.org/10.1007/BF02485951

3. CEN/TR 15177:2006. Testing the freeze-thaw resistance of concrete. Internal structural damage.

4. CEN/TS 12390-9. Testing hardened concrete - Part 9: Freeze-thaw resistance - Scaling.

5. Gjørv O. E. 2013 Durability design and quality assurance of major concrete infrastructure. Advances in Concrete Construction, Vol. 1, No. 1., pp. 45-63. https://doi.org/10.12989/acc.2013.1.1.045

6. EN 12390- 8: 2009 Testing hardened concrete - Part 8: Depth of penetration of water under pressure.

7. EN 12390-3: 2009 Testing hardened concrete - Part 3: Compressive strength of test specimens.

8. EN 12504-1: 2009 Testing concrete in structures - Part 1: Cored specimens - Taking, examining and testing in compression.

9. EN 12504-2: 2021 Testing concrete in structures - Part 2: Non-destructive testing - Determination of rebound number.

10. EN 13791:2007 Assessment of in-situ compressive strength in structures and precast concrete components.

11. EN 206:2013 Concrete - specification, performance, production and conformity.

12. GOST 10060-87. Concretes. Methods of frost resistance determination. Standart USSR. Moskow, Gosstroy USSR, 1987.14 p.

13. Hamoush S., Picornell-Darder M., Abu-Lebdeh T., Mohamed A. 2011. Freezing and Thawing Durability of Very High Strength Concrete. American Journal of Engineering and Applied Sciences. Vol. 4 (1), pp. 42-51. https://doi.org/10.3844/ajeassp.2011.42.51

14. LST 1428.19:2016 Concrete - Test methods - Part 19: Determination of frost resistance to one-sided freezing and thawing.

15. Mustafa I.H., Ibrahim G., Elkamel A., Elahwany A.H. 2009. Heterogeneous modeling, identification and simulation of activated sludge processes. American Journal of Environmental Science, Vol.5, pp. 352-363. https://doi.org/10.3844/ajessp.2009.352.363

16. Vaišvila K.A., Mikutskis F. 2005. Evaluation on the compressive strength of concrete by testing the samples of irregular shape. Civil Engineering'05: International Scientific Conference: Jelgava. (in Russian).

17. Zhang S. P., Zong L.2014. Evaluation of Relationship between Water Absorption and Durability of Concrete Materials. Advances in Materials Science and Engineering, D 650373. https://doi.org/10.1155/2014/650373

18. Zeinab A. E., Tamer I. A. 2018. Effect of freezing-thawing on concrete behaviour. Challenge Journal of Concrete Research Letters, Vol. 9(1), pp. 21-36. https://doi.org/10.20528/cjcrl.2018.01.003 